\title{
ON THE IMPERFECTIVE AND PERFECTIVE ASPECT IN ESTONIAN AND LATVIAN
}

\author{
Ilze Tālberga, Aive Mandel \\ University of Tartu
}

\begin{abstract}
This article presents a brief overview and comparison of the imperfective and perfective aspect in Estonian and Latvian. The main means of expressing the perfective and imperfective aspect in Estonian are the case opposition of the direct object (the nominative/genitive or the partitive), the use of verb particles, and the general context. In Latvian, the opposition of the perfective and imperfective aspect is mainly expressed by existence or absence of verb prefixes, adverbs, and also the context. In Latvian, verb prefixes, besides perfectivity, may also add or modify the lexical meaning of the verb. We compare how the perfective and imperfective aspect are expressed in both languages in the case of transitive verbs, based on the correspondences found in a text corpus of literary works and their translations.
\end{abstract}

Keywords: aspect, imperfective, perfective, verb, phrasal verbs, prefixes, adverbs, Latvian, Estonian

DOI: https://doi.org/10.12697/jeful.2017.8.1.13

\section{Introduction}

The present article focuses on the central distinctions within the aspect category, the imperfective and perfective aspect. The purpose of the article is to outline the most common means of expressing the perfective and imperfective aspect in Estonian and Latvian and to compare their practical use in both languages. In Estonian, the main means under observation are the object case opposition and the use of verbs with perfective verb particles and adverbials. In Latvian, we discuss the use of verb prefixes, unprefixed verbs, and adverbs.

A comparative overview of aspect in Estonian and Latvian has so far not been written. A number of authors have explored the Latvian or Estonian aspect separately. The Latvian aspect has been discussed by Ahero et al. (1959), Mathiassen (1997), Holvoet (2001), Soida (2009), Kalnača $(2005,2014)$, Horiguchi (2014), and others, while aspect in 
Estonian has been discussed, among others, by Metslang (2001), Erelt (2013), Norvik and Piiroja (2013). One can also find some comparative studies between different Baltic and Finnic languages: Estonian and Finnish (Sulkala 1996), Estonian, Finnish, and Lithuanian (Klaas 1999), and, from the Latvian point of view, a brief overview of aspect correspondences between Latvian and Finnish (Kalnača 2005). A small research has been done on the Latvian verb prefix $i e$ - and its correspondences in Estonian (Zagorska 2016), but the main focus of this article is on the equivalents of one Latvian prefix in Estonian, not on aspect in particular.

Studying in detail the differences and similarities of aspect between both languages is needed for better general understanding of how aspect operates in these and other neighbouring and related languages. It also helps to shed light on language contacts and encourages language teaching and learning as well as the development of further study materials and dictionaries of Estonian and Latvian.

The aim of the present article is to provide a preliminary comparative insight into Latvian and Estonian aspect. Chapter 2 introduces the method and the material of the study. Chapter 3 will review the general outline of aspect in Latvian and Estonian. In Chapters 4 and 5, the particular means for expressing perfectivity and imperfectivity in the case of transitive verbs are compared, using the examples from the corpus of literary translations between the two languages. Chapter 6 presents the conclusions about the differences and similarities between the expression of the perfective and imperfective aspect in both languages according to the examples from the text corpus.

\section{Method and material}

In this study, we firstly provide an outline of the main means for expressing the perfective and imperfective aspect in Estonian and Latvian. Secondly, the contrastive method is used to analyse the example sentences and their respective translations in both languages containing the described means. The analysis focuses on transitive verbs, leaving intransitive verbs for the further research. The current work presents a preliminary general outline of expressing the perfective and imperfective aspect in Estonian and Latvian and does not aim to provide a quantitative analysis or a complete list of all possible aspect correspondences. These issues are left for further investigation. 
As there is no public parallel Estonian and Latvian literary text corpus available, we use for our analysis examples taken from a selfmade text corpus that consists of Estonian and Latvian literary works and their translations.

The Estonian text corpus consists of two literary works: "Viimane Valgesulg" (1967) by Jaan Rannap and its translation "Pēdējais Baltspalvis" (1970) by Džuljeta Plakidis (further in the examples - R) and "Mina olin siin" (2005) by Sass Henno and its translation "Šeit biju es" (2006) by Maima Grīnberga-Preisa (further in the examples - H).

The Latvian text corpus consists of three Latvian literary works: "Aka" (1972) by Regīna Ezera and its translation "Kaev" (1990) by Valli Helde (further in the examples - E), "Gulta ar zelta kāju" (1984) by Zigmunds Skujinsš and its translation "Kuldjalaga voodi" (1989) by Oskar Kuningas (further in the examples - S), and "Meitene, kas nogrieza man matus" (2011) by Kristīne Želve and its translation "Juukselõikaja-tüdruk" (2014) by Hannes Korjus (further in the examples $-\check{Z}$ ).

\section{An outline of aspect in Estonian and Latvian}

In Estonian, similarly to the other Finnic languages, the perfective and imperfective aspect is not considered a consistent grammatical category of the verb as it is not expressed regularly or obligatorily. (EKG II: 25, Erelt 2013: 73) In Estonian as well as in Finnish, aspect is expressed rather at the level of the sentence (utterance) as it presents itself in the nouns connected to the verbs. (Kangasmaa-Minn 1984: 83-86, Sulkala 1996: 168-169) In the case of transitive verbs, the main grammatical means for marking the perfective and imperfective aspect is the opposition of the object cases, the total object in the nominative or the genitive, and the partial object in the partitive case (Erelt 2013: 73). Secondly, Estonian uses more often than Finnish the so-called bounders (particles connected to the verb) as lexical means for marking perfectivity in a sentence. In addition, aspect is expressed through verb semantics, semantics of the context, progressive constructions, and other means. (EKG II: 25-26, Sulkala 1996: 169, Klaas 1999, Metslang 2001: 443, Erelt 2013: 74) As Klaas (1996: 43) points out, one can observe a transition from the Finnic nominal and synthetic aspect towards the Indo-European analytical verbal aspect in Estonian. 
In Latvian there is no generally agreed treatment of the verb aspect it has been postulated as a grammatical category (Ahero et al. 1959, Mathiassen 1997) or a lexical grammatical category (Paegle 2003, Kalnača 2004). Usually, Latvian verb aspect is expressed by two means: opposition of the imperfective/perfective aspect (unprefixed/prefixed verb) and the semelfactive/iterative aspect (unsuffixed/suffixed verb) (Paegle 2003: 132, Kalnača 2013: 533, Kalnača 2014: 91). The imperfective and perfective aspect in Latvian is expressed in two ways: morphologically and syntactically. The imperfective and perfective aspect is expressed morphologically by using the opposition between an unprefixed verb (imperf.) and a prefixed verb (perf.). It is expressed syntactically first of all by an opposition between an unprefixed verb + adverb (imperf.) and a prefixed verb (perf.), and secondly by bi-aspectual verbs, which express imperfectivity and/or perfectivity in the contextual use, not by a prefix. (Kalnača 2013: 533, Kalnača 2014: 92).

In the case of Latvian verb aspect, there are several nuances that should be taken into account, such as the lexical meaning of the verb, the word-formation means (prefixes and suffixes), semantics of the context, verb tense forms, etc. (Paegle 2003: 131, Kalnača 2013: 531, Kalnača 2014: 89) According to Kalnača (2014: 89), the verb aspect "is simultaneously a word formation and a contextual phenomenon; the expression of the form is connected with different linguistic features: derivative, lexical, morphological, morphonological, and syntactic".

Aspect in Latvian is generally modulated by a verb and in Estonian by a noun case alteration or verb particle constructions. Both languages use different means: morphological, grammatical, syntactic, and lexical. In the following chapters we will observe more closely the particular means for expressing the perfective and imperfective aspect.

\section{Means of expressing perfectivity in Estonian and Latvian}

Regarding Estonian, we will mainly discuss two possibilities for marking perfectivity in the perfective/imperfective opposition. Firstly, perfectivity is expressed by the total object in the genitive singular (Ostsin uue kleidi. 'I bought a new dress'), the nominative singular (Osta uus kleit! 'Buy a new dress!'), or the nominative in the plural (Ostsin uued püksid. 'I bought new trousers'). The choice of the object case depends on several factors, among others verb semantics (aspect of the verb). Verbs that semantically express imperfective activity are 
called partitive verbs (e.g. armastama 'to love', mõtlema 'to think') and they usually take the partial object. Perfective verbs (e.g. kaotama 'to lose') take the total object. The third group of verbs called neutral or aspect verbs (mostly transitive, e.g. ehitama 'to build') can take both, the partial or the total object, which in turn defines the aspect of the sentence. (Erelt 2013: 72-73)

Secondly, perfectivity can be marked in Estonian by bounders - perfective verb particles such as ära 'away, off', läbi 'through', välja 'out', üles 'up' and adverbials, e.g. lõpuni 'till the end', täielikult 'completely'. (Erelt 2013: 73-74) Of these, the particle ära is the most frequent and least ambiguous marker of perfectivity. (EKG II: 25, Metslang 2001: 444) In the case of perfective and aspect verbs, such bounders only stress the perfectivity already expressed through verb semantics or the total object. In the case of transitive aspect verbs, however, the bounders help to overcome synonymy of the object cases, caused in Estonian by changes in case endings (apocope). (Metslang 2001: 444-445, Erelt 2013: 74) For example, in the sentence Kass sõi kala. ('A cat ate the fish' / 'A cat was eating (some) fish') the direct object kala 'fish' could equally be interpreted as the genitive case marking perfectivity or the partitive case marking imperfectivity. Adding ära makes the sentence unambiguously perfective: Kass sõi kala ära 'The cat ate up the fish'. Bounders also allow changing the aspect of imperfective (partitive) verbs into perfective, in which case they serve as the main and obligatory perfectivity markers: Jüri luges raamatu läbi. 'Jüri read the book through.' (Erelt 2013: 75) Such bounders carry a clear perfective meaning and their use for expressing the perfective aspectual meaning is spreading in Estonian, showing the need for a more clear analytical marker connected to a verb (Metslang 2001: 444).

In Latvian, the main device for marking the perfective and imperfective aspect is the use of verb prefixes. There are 11 verb prefixes in Latvian (aiz-, ap-, at-, ie-, iz-, no-, pa-, pār-, pie-, sa-, uz-) and besides changing imperfect (unprefixed) verbs into perfect (prefixed) verbs, they also may have a second purpose - to change, modulate, or create a new lexical meaning of a verb in a spatial, temporal, or quantitative way. (Mathiassen 1997: 118, Soida 2009: 228, Kalnača 2013: 534, Kalnača 2014: 93). The verb without a prefix carries an imperfective meaning: Es lasīju grāmatu 'I was reading a book', while prefix changes the meaning into perfective Es izlasīju grāmatu 'I read the book through / I finished reading a book'.

All 11 prefixes make verbs perfective and modulate the lexical meaning of the verb, but in a few cases the prefix may give only a 
perfective meaning (without adding or changing the lexical meaning of the verb), e.g. pirkt - nopirkt 'to buy' (Ahero et al. 1959: 567, Kalnača 2013: 534). The negative prefix $n e$ - is the only prefix that is not connected to aspect; it only makes the verb negative ne-pirkt (imperf.) 'not to buy' - ne-no-pirkt (perf.) 'not to buy' (Kalnača 2013: 534, Vulāne 2013: 281, Kalnača 2014: 93).

In Latvian, in the case of directional verbs, it is also possible to add an adverb to an already prefixed verb, e.g. ieiet iekša 'to go inside', where the adverb supposedly repeats and strengthens the direction, which is already expressed by the prefix and therefore is not supposed to be connected to the verb aspect. (Ahero et al. 1959: 578, Kalnača 2014: 99).

The following examples from the corpora of Latvian and Estonian literary translations give an overview of the correspondences in expressing perfectivity in both directions - from Estonian into Latvian and from Latvian into Estonian, using the previously mentioned markers.

\subsection{Estonian total object (genitive/nominative) and Latvian prefixed verb}

\subsubsection{Estonian total object (genitive/nominative) > Latvian prefixed verb}

In example 1a, the Estonian direct object toit 'food' is used in the genitive singular marking the action as perfective. In Latvian perfectivity is expressed by using the verb prefix $i e$ - which also expresses the directional meaning 'into', supporting the noun refrigerator.
a. Pois
$\begin{array}{llll}\text { Poiss } & \text { viskas } & \text { toidu } & \text { külmkappi } \\ \text { boy.NOM } & \text { threw.PST.3SG } & \text { food.GEN } & \text { refrigerator.ILL }\end{array}$
Puisis ie-meta èdienu ledusskap̄
boy.NOM PREF-throw.PST.3SG food.ACC refrigerator.LOC
'The boy threw the food into the refrigerator.'

In example $1 \mathrm{~b}$, the Estonian direct object mõned kaunimad portreed 'some beautiful portraits' is in the nominative plural, which marks perfectivity. In Latvian, again, perfectivity is expressed by the verb prefix pie-.

1 The English translations are given according to the first example. 
b. /.../ kinnitas üliõpilane mõned kaunimad attach.PST.3SG student.NOM some.PL.NOM beautiful.SUPL.PL.NOM portreed oma voodi kohale. (R, 45) portrait.PL.NOM own.GEN bed.GEN above.ALL /.../ students dažas skaistākās student.NOM.M some.PL.ACC beautiful.suPL.PL.ACC fotogrāfijas pie-stiprināja virs savas photograph.PL.ACC PREF-attach.PST.3SG above own.GEN.F gultas. $(\mathrm{R}, 41)$

bed.GEN

$\%$.../ the student attached some of the most beautiful portraits above his bed.'

\title{
4.1.2. Latvian prefixed verb $>$ Estonian total object (genitive/nominative)
}

In example $2 \mathrm{a}$, the Latvian prefixed verb atrisinat 'to solve' is the perfective of the verb risināt 'to solve' and the prefix at- has only the perfective meaning. It is translated into Estonian by using the direct object paisuv konflikt 'emerging conflict' in the genitive singular (total object), which marks perfectivity.

\author{
(2) a. /.../ Rūdolfs steigšus at-risināja briestošo \\ Rudolf.NOM quickly PREF-solve.PST.3SG emerging.PTCP.ACC \\ konfliktu. (E, 260) \\ conflict.ACC \\ $\begin{array}{llll}\text { /.../ lahendas } & \text { Rūdolf } & \text { kiiresti } & \text { paisuva } \\ \text { solve.PST.3SG } & \text { Rudolf.NOM } & \text { quickly } & \text { emerging.PTCP.GEN }\end{array}$ \\ konflikti. (E, 192) \\ conflict.GEN \\ 'Rudolf quickly solved the emerging conflict.'
}

In example $2 b$, the Latvian prefixed verb nonemt 'to take off' is the perfective of the verb nemt 'to take' and additionally the prefix no- also supports the direction of the noun phrase no kressla atzveltnes 'from the back of the chair'. In Estonian, perfectivity is expressed by the direct object riided 'clothes' in the nominative plural (total object). 


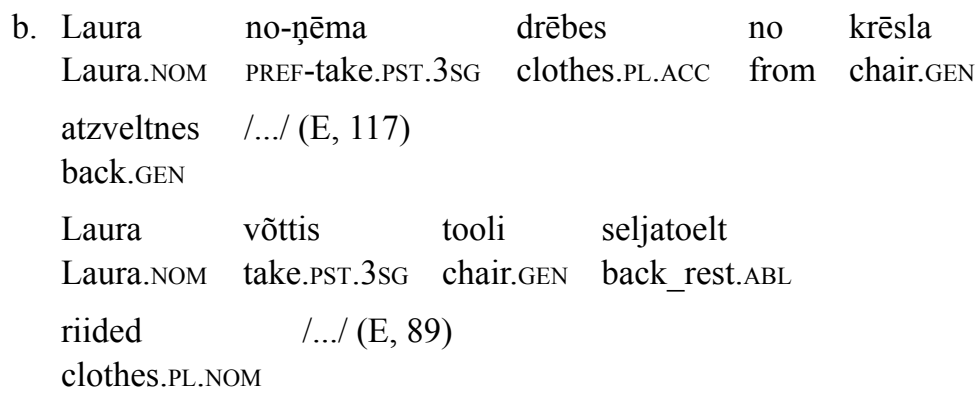

'Laura took the clothes from the back of a chair.'

The previous examples show that while perfectivity in Estonian is expressed by the direct object in the genitive (singular) or the nominative (plural), in Latvian perfectivity may be expressed by the verb prefix and vice versa. In addition, the verb prefix in Latvian also adds some extra meaning to the verb, supporting the noun or the noun phrase in the directional meaning.

\subsection{Estonian total object (genitive/nominative) + verb particle and Latvian prefixed verb and prefixed verb + adverb}

\subsubsection{Estonian total object (genitive/nominative) + verb particle $>$ Latvian prefixed verb}

In example 3a, perfectivity in Estonian is expressed by two means the direct object aken 'window' in the genitive singular and the verb particle kinni 'closed, shut' together with the verb panema 'to put'. The verb particle kinni supports the direction. It is translated into Latvian by the prefixed verb aiztaisit 'to shut' (the perfective form of verb taisit 'to do'), where the prefix aiz- expresses both perfectivity and direction. In addition, in Latvian it is also be possible to add the adverb ciet 'close' to the prefixed verb (about the prefixed verb + adverb see 4.2.3.)

(3) a. Poiss pani akna kinni /... $(\mathrm{H}, 47)$

boy.NOM put.PST.3sg window.GEN shut

Puisis aiz-taisīja $\quad \operatorname{logu} / \ldots / \quad(\mathrm{H}, 5: 08)$

boy.NOM PREF-shut.PST.3SG window.ACC

'The boy shut the window.' 
In example 3b, perfectivity in Estonian is expressed also by two means - the direct object in the nominative plural teksad 'jeans' and the verb particle ära with the verb pesema 'to wash'. The verb particle ära does not add any directional meaning; here it is purely a perfective marker. In Latvian, the prefixed verb izmazgāt 'to wash (clean)' is the perfective form of the verb mazgāt 'to wash', and similarly to the Estonian verb particle $\ddot{a} r a$, the prefix $i z$ - in this case has only the perfective meaning.

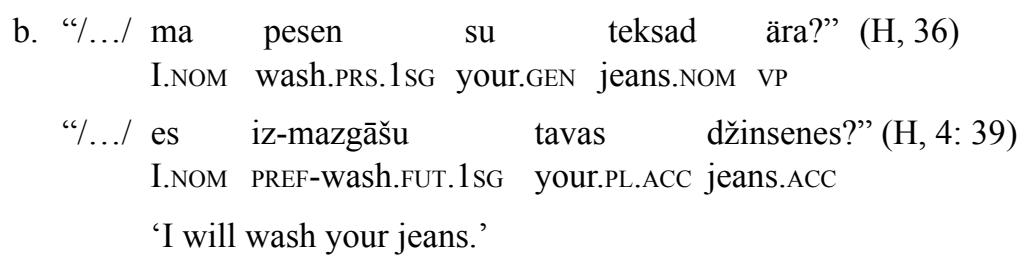

\subsubsection{Latvian prefixed verb $>$ Estonian total object (genitive/nominative) + verb particle}

In example 4a, the Latvian prefixed verb atkorkseet 'to uncork' is the perfective of the verb korkseet 'to cork', and the prefix at- means the same as the adverb val $\bar{a}$ ' 'open'; therefore it has two meanings - perfective and directional. In Estonian, perfectivity is expressed by the direct object šampanja 'champagne' in the genitive singular and the verb particle lahti 'open' together with the verb korkima 'to cork'.

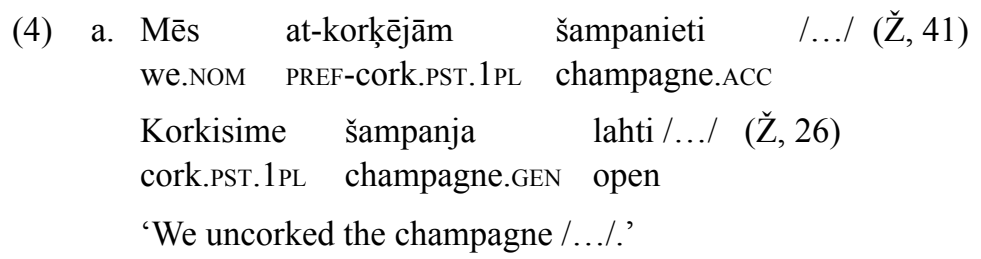

In example $4 \mathrm{~b}$, the Latvian prefixed verb pierakstīt 'to write' is perfective of the verb rakstit 'to write' and the prefix pie- adds a perfective meaning. In Estonian perfectivity is expressed by the direct objects ideed 'ideas' and motted 'thoughts' in the nominative plural and the verb particle üles 'up' together with the verb kirjutama 'to write'. 
b. /.../ kladīti, kurā pie-rakstīju idejas notebook.ACC which.LOC PREF-write.PST.1SG idea.PL.ACC

filmām, romāniem, stāstiem un savas film.PL.DAT novel.PL.DAT story.PL.DAT and own.PL.ACC domas. $\quad(\check{Z}, 29)$ thoughts.PL.ACC

$\begin{array}{lllll}\text { /.../ klade, } & \text { kuhu } & \text { kirjutasin } & \text { üles } & \text { oma } \\ \text { notebook.GEN } & \text { where.ILL } & \text { write.PST.1sG } & \text { up } & \text { own.GEN }\end{array}$ filmide, romaanide, juttude ideed ja film.PL.GEN novel.PL.GEN story.PL.GEN idea.PL.NOM and oma mõtted $(\check{Z}, 19)$

own.GEN thought.PL.NOM

'.../ notebook where I wrote down the ideas for films, novels, stories, and my thoughts.'

\subsubsection{Estonian total object (genitive/nominative) + verb particle $>$ Latvian prefixed verb + adverb}

Example 5 in Estonian is similar to example 3 a where perfectivity is expressed by the direct object - majauks 'house door' in the genitive singular and the verb particle lahti 'open' together with the verb lükkama 'to push'. The Latvian translation in example 5 differs from 3a because besides perfectivity, which is expressed by the prefixed verb atgrüst 'to push' (perfective of the verb grüst 'to push') where the prefix at- means 'open', there is also an additional adverb vals $\bar{a}$ 'open'.
(5) Tüdruk lükkas majaukse lahti. (R, 31) girl.NOM push.PST.3sG house_door.GEN open

Meitene at-grūda vaļā mājas durvis (R, 4:23) girl.NOM PREF-push.PST.3sG open house.GEN door.PL.ACC
'The girl pushed the door house open.'

As mentioned in Chapter 2, an adverb can be added to an already prefixed verb; however, perfectivity is already manifested by the verb prefix, therefore the adverb does not directly change or influence perfectivity. The adverb is added only for emphasizing the direction. 


\subsubsection{Latvian prefixed verb + adverb $>$ Estonian total object (genitive/nominative) + verb particle}

Example 6 in Latvian is similar to example 5 where the prefixed verb izlikt 'to lay out' (perfective of the verb likt 'to lay'), where prefix $i z$ - expresses both perfectivity and the direction 'out', is complemented by the adverb lauka 'out', having the same meaning as the verb prefix. It is translated into Estonian in the same way as in example 4a, and here perfectivity is expressed by the direct object kraam 'belongings, stuff' in the genitive singular and the verb particle välja 'out' together with the verb laduma 'to lay'. The Latvian adverb does not influence the translation into Estonian since the prefixed verb already expresses perfectivity.

$$
\begin{aligned}
& \text { /.../ vinšs tikai iz-lika laukā mantas /.../(S, 223) } \\
& \text { he.NOM only PREF-lay.PST.3sG out belongings.ACC } \\
& \text { /.../ ta ainult ladus } \quad \text { välja kraami /.../(S, 161) } \\
& \text { he.NOM only PREF-lay.PST.3SG out belongings.GEN } \\
& \text { \%.../ he only laid out belongings /.../.' }
\end{aligned}
$$

These examples reveal that perfectivity in Estonian is also expressed by a verb particle and the total object (genitive/nominative). In this case the basic correspondence in Latvian is still a prefixed verb. In Latvian perfectivity of the prefixed verb can be translated into Estonian also by a verb particle and the total object. However, in Latvian it is also possible to add an adverb to the prefixed verb, but in Estonian it will still be a verb particle - regardless of the presence or absence of an adverb with a prefixed verb.

\section{Means of expressing imperfectivity in Estonian and Latvian}

When aspect is expressed through case alternation in Estonian, the partial object in the partitive case can have an imperfective interpretation, e.g. Linnud ehitasid pesasid. - 'The birds were building nests.' Sometimes, however, both imperfective and perfective interpretations are possible: Tõin turult maasikaid. - 'I brought / was bringing some strawberries from the market.' Since aspect is not a regularly expressed category in Estonian, it can be unspecified in the case of durative situations, and a particular interpretation of the aspect depends on the time and aspect of the context. (EKG II: 25) 
In Latvian, however, an unprefixed verb expresses imperfectivity. The following examples present the correspondences of the imperfective aspect of Estonian and Latvian in literary translations.

\subsection{Estonian partial object (partitive) and Latvian unprefixed verb}

\subsubsection{Estonian partial object (partitive) $>$ Latvian unprefixed verb}

In example 7 the Estonian direct object moosipirukas 'jam pie' is in the partitive singular, which, according to the context, means that the action is imperfective - it does not specify how many pies were baked. In the Latvian translation this partiality (imperfectivity) is expressed by the unprefixed verb cept 'to bake'.

$\begin{array}{lllll}\text { (7) Ema } & \text { küpsetas } & \text { köögis } & \text { moosipirukat. } & (\mathrm{R}, 40) \\ \text { mother.NOM } & \text { bake.PST.3SG } & \text { kitchen.INE } & \text { jam_pie.PART } & \\ \text { Virtuvē } & \text { māte } & \text { cepa } & \text { pīrāgus } & \text { ar } \\ \text { kitchen.LOC } & \text { mother.NOM } & \text { bake.PST.3SG } & \text { pie.PL.ACC } & \text { with } \\ \begin{array}{l}\text { ievārījumu. } \\ \text { jam.ACC }\end{array} & (\mathrm{R}, 37) & & \\ \text { 'Mother was baking a jam pie in the kitchen.' }\end{array}$

\subsubsection{Latvian unprefixed verb $>$ Estonian partial object (partitive)}

In example 8 the Latvian unprefixed verb èst 'to eat' expresses imperfectivity; it does not specify how much of the bread was eaten and if it was eaten up. In the Estonian translation imperfectivity is expressed by the direct object leib 'bread' in the partitive. Therefore, it expresses the same meaning as in Latvian - the amount of the bread eaten and the end of the action (completeness) are unspecified.
(8)

$\begin{array}{lllll}\text { Mēs } & \text { kopā } & \text { edām } & \text { maizi. } & \text { (E, 101) } \\ \text { we.NOM } & \text { together } & \text { eat.PST.1PL } & \text { bread.ACC } & \\ \text { Me } & \text { sõime } & \text { koos } & \text { leiba. } & \text { (E, 77) } \\ \text { we.NOM } & \text { eat.PST.1PL } & \text { together } & \text { bread.PART } & \\ \text { 'We were eating bread together.' } & & \end{array}$




\subsection{Estonian partial object (partitive) and Latvian unprefixed verb + adverb}

In Latvian, in addition to the morphological means of expressing the perfective/imperfective opposition by a prefixed and an unprefixed verb, it can be expressed also syntactically by opposing a prefixed verb (e.g. ieiet (perf.) 'to go in') with the construction unprefixed verb + adverb (e.g. iet iekša $\bar{a}$ (imperf.) 'to go in') (Kalnača 2013: 535). This construction is used mainly in spatial orientation where spatial adverbs correspond to the corresponding verb prefix(es) and express movement towards a certain goal (Ahero et al. 1959: 571). According to Kalnača (2014: 98), "the verb and adverb in these constructions do not form a monolithic lexical, morphological, and syntactic unit, as the adverb has not grammaticalized and has preserved its adverbial function in the sentence, its independent word stress, and its adverbial meaning". This construction can be used in the present tense if the prefixed (perfective) form is not suitable and also in other cases when the imperfective action in spatial orientation needs to be expressed (Ahero et al. 1959: 576, Kalnača 2013: 537).

\subsubsection{Estonian partial object (partitive) $>$ Latvian unprefixed verb + adverb}

In example 9 in Estonian the direct object kolmeteistkümnes 'thirteenth' is used in the partitive singular expressing imperfectivity and is accompanied by the adverb parajasti 'currently', meaning that the person was fishing [out] the thirteenth mouse from the blades of grass. It is translated into Latvian by the verb makškserèt 'to fish' with an adverb lauk $\bar{a}$ 'out' and forms the construction unprefixed verb + adverb, which expresses imperfectivity.

$\begin{array}{lllll}\text { (9) Parajasti } & \text { õngitses } & \text { ta } & \text { rohukõrte } & \text { vahelt } \\ \text { currently } & \text { fish.PST.3SG } & \text { he.NOM } & \text { blade_of_grass.PL.GEN } & \text { among.ABL }\end{array}$

kolmeteistkümnendat. (R, 41)

thirteenth.PART

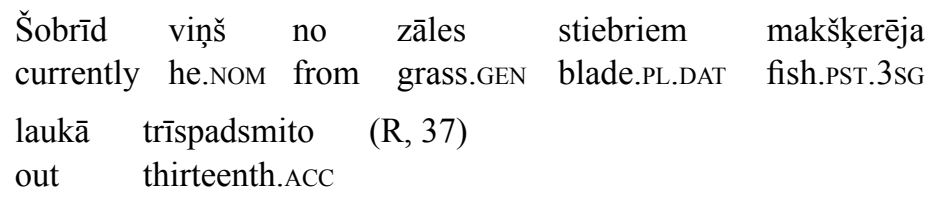

'He was currently fishing out the thirteenth [mouse] from blades of grass.' 


\subsubsection{Latvian unprefixed verb + adverb $>$ Estonian partial object (partitive)}

In example 10 imperfectivity is expressed by all of the given verbs, but the verb lauzt 'to break' is used with the adverb vals $\bar{a}$ 'open', forming the imperfective construction unprefixed verb + adverb. In Estonian the direct object tünnid 'barrels' is in the plural partitive, which marks imperfectivity, and the verb particle lahti 'open' and the verb kangutama 'to pry' are used.

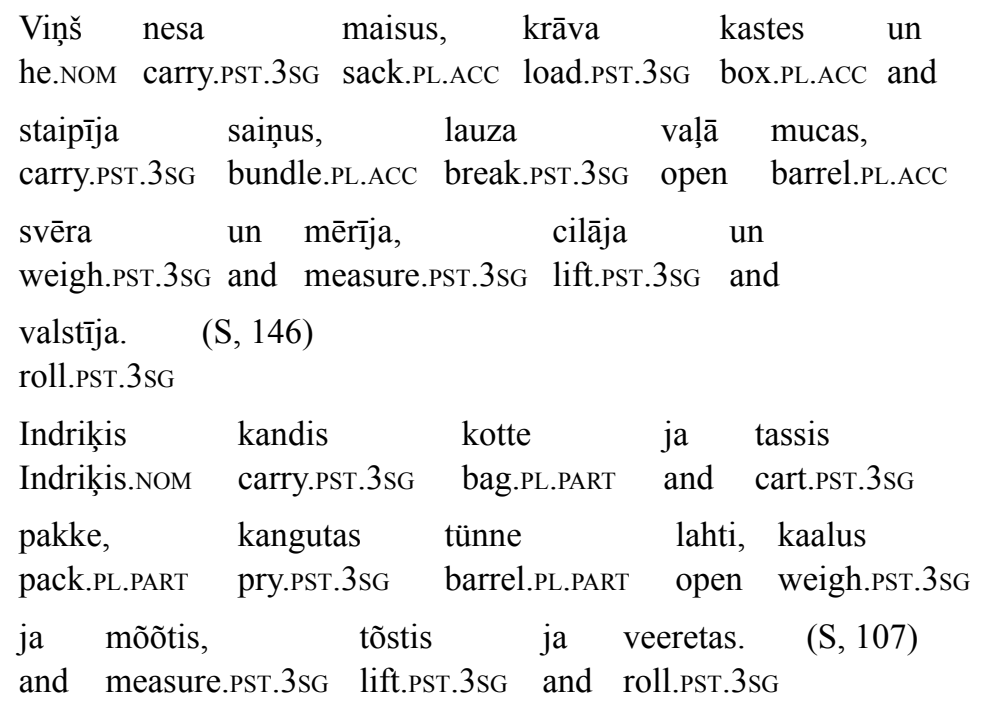

'Indrikis carried sacks and packages, broke open barrels, weighed and measured, lifted and rolled.'

\subsection{Estonian progressive and Latvian unprefixed verb}

In some cases the imperfective and perfective aspect are expressed by less central means or by markers, which may leave the aspect interpretation open. This is also reflected in the translations of Estonian and Latvian literary works. It has been argued whether or not the progressive can be categorized under imperfectivity (Norvik and Piiroja 2013: 61-62). In Estonian the progressive is the construction of the verb olema 'to be' and the inessive of the main verb in the $m a$-infinitive, carrying locative, momentary, gradual, or other meanings (Sulkala 1996: 195-196, Metslang 2006: 4-5). The translation corpus shows 
some cases of its correspondences with Latvian unprefixed verbs expressing imperfectivity (examples 11 and 12).

\subsubsection{Estonian progressive $>$ Latvian unprefixed verb}

In example 11 the Estonian verbs onngitsema 'to fish' and kõplama 'to hoe' are used in the progressive expressing imperfectivity, and the latter verb is complemented by the direct object kooliaed 'school garden' in the partitive. In the Latvian translation imperfectivity is expressed by the unprefixed verbs nemakškserēt 'not to fish' and kaplèt 'to hoe'.

(11) Nad pole sugugi jõesuudmes õngitsemas ega they.NOM not not_at_all river_mouth.INE angle.INF.INE nor kooliaeda kõplamas /.../ $(\mathrm{R}, 134)$

school_garden.PART hoe.INF.INE

Viņi nebūt nemakškserē upes grīvā, nedz arī they.NOM not_at_all not_fish.PRS.3PL river.GEN mouth.LOC nor kaplē skolas dārzā, /.../ $(\mathrm{R}, 130)$ hoe.PST.3PL school.GEN garden.LOC

'They are not at all angling at the river mouth or hoeing the school garden /....'.'

\subsubsection{Latvian unprefixed verb $>$ Estonian progressive}

In example 12 the Latvian unprefixed verb mest 'to cast' expresses imperfectivity, which is translated into Estonian with the verb heitma 'to cast' in the progressive, complemented by the direct object varjud 'shadows' in the partitive plural.

$$
\begin{aligned}
& \begin{array}{llll}
\text { /.../ garās } & \text { skropstas } & \text { meta } & \text { enas } \\
\text { long.DEF.PL.NOM } & \text { eyelash.PL.NOM } & \text { cast.PST.3PL } & \text { shadow.PL.ACC }
\end{array} \\
& \text { uz brūnajiem vaigiem. } \quad(\mathrm{E}, 20) \\
& \text { on brown.DEF.PL.DAT cheek.PL.DAT } \\
& \text { /.../ pikad ripsmed heitmas varje } \\
& \text { long.PL.NOM eyelash.PL.NOM throw.INF.INE shadow.PL.PART } \\
& \text { pruunidele põskedele. (E, 17) } \\
& \text { brown.PL.ALL cheek.PL.ALL } \\
& \text { ‘.../ long eyelashes casting shadows on the brown cheeks.' }
\end{aligned}
$$


The examples suggest that in Estonian the imperfective aspect is expressed by the direct object in the partitive and in Latvian by an unprefixed verb. The Latvian correspondence of the Estonian partitive is also the construction unprefixed verb + adverb and vice versa, which emphasizes spatiality. The Latvian correspondence of an Estonian progressive verb is an unprefixed verb and vice versa. It should be mentioned that the Estonian progressive verb was not frequent in the translation corpus. Thus, one can conclude that the progressive is possible in Estonian but is not very common.

\section{Conclusion}

The aim of the present article was to provide an overview and comparison of the imperfective and perfective aspect in Estonian and Latvian. The analysis focused on transitive verbs, leaving intransitive verbs for further research. The examples for the comparison were taken from the text corpus of Estonian and Latvian literary works (compiled by the authors), and their translations.

Perfectivity in Estonian is primarily expressed by the total object (the direct object in the genitive singular, nominative plural and singular) and imperfectivity by the partial object (partitive). In Latvian the perfective aspect is mainly expressed by 11 verb prefixes (aiz-, ap-, at-, ie-, iz-, no-, pa-, pār-, pie-, sa-, uz-), which, in addition to perfectivity, may (or may not) change or modify the lexical meaning of the verb on the spatial, quantitative, or qualitative level. In the first examples we can see that perfectivity expressed by the Estonian total object corresponds to a Latvian verb prefix, the same applies for the opposite direction of translation. Additionally, a Latvian verb prefix has in these cases an additional meaning besides perfectivity.

Secondly, perfectivity in Estonian may be expressed by a verb particle (e.g. ära - 'away') that either contributes to the total object reflecting perfectivity or is even obligatory in some cases. Comparison of the translations reveals that the meaning of the Estonian verb particle can be expressed by the Latvian verb prefix, which may have an additional meaning (aiz- 'closed') or not (iz-magāt - 'to wash'), the latter expressing only perfectivity. Estonian verb particles can be translated into Latvian by a prefixed verb with the corresponding adverb. An adverb with a prefixed verb is, however, not considered as part of aspect since a prefixed verb already expresses the perfectivity. Thus, it 
can be interpreted as an additional directional marker. Both translation directions show that if a Latvian verb has a prefix, the adverb does not influence the translation - the correspondence is the same as in the case of only a prefixed verb, as the prefix already expresses direction. Both languages use adverbs in parallel.

Imperfectivity is in Estonian expressed by the partial object (the direct object in the partitive, both singular and plural), which depending on the context may express either imperfectivity or perfectivity. In Latvian an unprefixed verb serves as the marker of imperfectivity, which is also observed in both translations. Additionally, imperfectivity can be expressed in Latvian by the construction unprefixed verb + adverb where the adverb is synonymous with the corresponding prefix(es). In this construction, the verb prefix is replaced by an adverb with the same meaning expressing imperfectivity. In the Estonian translation, this construction has a partial object. Also, a small number of cases could be found where the Latvian unprefixed verb had the progressive construction as its correspondence in Estonian.

This short study has revealed some parallels, differences, and similarities in the correspondences of the perfective and imperfective opposition in Estonian and Latvian. However, the present study is only an initial introduction to a very broad topic. In future it would be useful to take a much broader perspective (involving intransitive verbs and extended treatment of aspect) and to use more comprehensive research material.

\section{Addresses:}

Ilze Tālberga

University of Tartu

College of Foreign Languages and Cultures

Lossi 3-424

51003 Tartu, Estonia

E-mail: ilze.talberga@ut.ee

Aive Mandel

University of Tartu

Jakobi 2

51014 Tartu, Estonia

E-mail: aivem@ut.ee 


\begin{abstract}
Abbreviations
1 - first person, 3 - third person, ABL - ablative, ACC - accusative, ALL - allative, DAT - dative, DEF - definitive, F - feminine, FUT - future, GEN - genitive, INE - inessive, INF - infinitive, M - masculine, NOM nominative, PART - partitive, PL - plural, PREF - prefix, PRS - present, PST - past, PTCP - participle, SG - singular, SUPL - superlative, VP - verb particle
\end{abstract}

\title{
References
}

Ahero, Antonija et al. (1959) Mūsdienu latviešu literārās valodas gramatika I. Fonētika un morfologija. Rīga: LPSR ZA izdevniecība.

EKG II = Mati Erelt, Reet Kasik, Helle Metslang, Henno Rajandi, Kristiina Ross, Henn Saari, Kaja Tael ja Silvi Vare (1993) Eesti keele grammatika II. Süntaks. Trükki toimetanud Mati Erelt (peatoimetajana), Tiiu Erelt, Henn Saari, Ülle Viks. Tallinn: Eesti Teaduste Akadeemia Keele ja Kirjanduse Instituut.

Erelt, Mati (2013) Eesti keele lauseõpetus. Sissejuhatus. Öeldis. Tartu Ülikooli eesti keele osakonna preprindid. 4. Tartu: Tartu Ülikool.

Holvoet, Axel (2001) Studies in the Latvian verb. Krakow.

Horiguči, Daiki (2014) "Some remarks on Latvian aspect." In Andra Kalnača and Ilze Lokmane, eds. Valoda: nozìme un forma. 4. Kategoriju robežas gramatikā, 22-32. Rīga: LU Akadēmiskais apgāds.

Available online at $<$ http://www.lu.lv/apgads/izdevumi/elektroniskie-izdevumi/zurnaliun-periodiskie-izdevumi/valoda-nozime-un-forma/valoda-nozime-un-forma-4/> . Accessed on 09.02.2017.

Kalnača, Andra (2004) "Darbības vārda veida kategorijas realizācija latviešu valodā." Linguistica Lettica 13, 5-34. Rīga: Latviešu valodas institūts.

Kalnača, Andra (2005) "A study of aspect correspondences between Latvian and Finnish.” Kalbu studijos/Studies about Languages 7, 26-29. Available online at $<$ http://www.kalbos.lt/zurnalai/07_numeris/05.pdf > . Accessed on 14.12.2016.

Kalnača, Andra (2013) "Darbības vārds (verbs)". In Ilze Auziņa, Ieva Breņķe, Juris Grigorjevs, Inese Indričāne, Baiba Ivulāne, Andra Kalnača, Linda Lauze, Ilze Lokmane, Dace Markus, Daina Nīinna, Gunta Smiltniece, Baiba Valkovska, and Anna Vulāne, eds. Latviešu valodas gramatika, 456-563. Rīga: LU Latviešu valodas institūts.

Available online <http://www.lulavi.lv/media/upload/tiny/files/LVG_satura\%20raditajs.pdf $>$. Accessed on 09.02.2017.

Kalnača, Andra (2014) A typological perspective on Latvian grammar. Berlin: De Gruyter Open.

Kangasmaa-Minn, Eeva (1984) “Tense, aspect and aktionsart in Finno-Ugrian.” In Casperde Groot and Hannu Tommola, eds. Aspect bound. A voyage into the realm 
of Germanic, Slavonic and Finno-Ugrian aspectology, 77-93. Dordrecht: Foris Publications.

Klaas, Birute (1996) "Similarities in case marking of syntactic relations in Estonian and Lithuanian.” In Mati Erelt, ed. Estonian: Typological Studies IV, 37-67. (Tartu Ülikooli eesti keele õppetooli toimetised 4.) Tartu: University of Tartu.

Klaas, Birute (1999) "Dependence of the object case on the semantics of the verb in Estonian, Finnish, and Lithuanian.” In Mati Erelt, ed. Estonian: Typological Studies III, 47-83. (Tartu Ülikooli eesti keele õppetooli toimetised 11.) Tartu: University of Tartu.

Mathiassen, Terje (1997) A short grammar of Latvian. Ohio: Slavica Publishers.

Metslang, Helle (2001) "On the developments of the Estonian aspect. The verb particle ära." In Östen Dahl and Maria Koptjevskaja-Tamm, eds. The Circum-Baltic languages 2: Grammar and typology, 443-479. Amsterdam: John Benjamins.

Metslang, Helle (2006) "Predikaat ajastut kogemas." Keel ja Kirjandus 9, 714-727.

Norvik, Miina and Piret Piiroja (2013) “Aeg ja aspekt.” In Ilona Tragel, Ann Veismann, and Piret Piiroja, eds. Theoretical linguistics in Estonia III, 53-72. (Eesti ja soomeugri keeleteaduse ajakiri. Journal of Estonian and Finno-Ugric Linguistics 4(1).) Tartu: University of Tartu Press.

Paegle, Dzintra (2003) Latviešu literārās valodas morfologija. I daḷa. Rīga: Zinātne.

Soida, Emīlija (2009) Vārddarināšsana. Rīga: LU Akadēmiskais apgāds.

Sulkala, Helena (1996) “Expression of aspectual meanings in Finnish and Estonian.” In Mati Erelt, ed. Estonian: Typological Studies I, 165-225. (Tartu Ülikooli eesti keele õppetooli toimetised 4.) Tartu: University of Tartu.

Zagorska, Ilze (2016) "Expressing the Latvian verb prefix ie- in Estonian." In Andra Kalnača, Ilze Lokmane, and Daiki Horiguči, eds. Valoda: nozìme un forma. 7. Gramatika un saziña, 235-247. Rīga: LU Akadēmiskais apgāds.

Vulāne, Anna (2013) "Vārddarināšana.” Latviešu valodas gramatika. In Ilze Auziṇa, Ieva Breņķe, Juris Grigorjevs, Inese Indričāne, Baiba Ivulāne, Andra Kalnača, Linda Lauze, Ilze Lokmane, Dace Markus, Daina Nīinna, Gunta Smiltniece, Baiba Valkovska, and Anna Vulāne, eds. Latviešu valodas gramatika, 190-299. Rīga: LU Latviešu valodas institūts.

Available online <http://www.lulavi.lv/media/upload/tiny/files/LVG_satura\%20raditajs.pdf $>$. Accessed on 09.02.2017.

\section{Corpora sources}

(E) Ezera, Regīna (1972) Aka. Rīga: Liesma.

Ezera, Regīna (1990) Kaev. Tõlkinud Valli Helde. Tallinn: Eesti Raamat.

(H) Henno, Sass (2005) Mina olin siin. Esimene arest. Eesti Päevalehe AS.

Henno, Sass (2006) Šeit biju es. Pirmais arests. No igauņu valodas tulkojusi Maima Grīnberga-Preisa. Laiksraksts Diena.

(R) Rannap, Jaan (1967) Viimane Valgesulg. Tallin: Eesti Raamat.

Rannaps, Jāns (1970) Pēdējais Baltspalvis. Rīga: Liesma. 
(S) Skujiņš, Zigmunds (1984) Gulta ar zelta kāju. Rīga: Liesma.

Skujinš, Zigmunds (1989) Kuldjalaga voodi. Läti keelest tõlkinud Oskar Kuningas.

Tallinn: Eesti Raamat.

(Ž) Želve, Kristīne (2011) Meitene, kas nogrieza man matus. Rīga: Mansards.

Želve, Kristīne (2014) Juukselõikaja-tüdruk. Läti keelest tõlkinud Hannes Korjus. Tallinn: Kultuurileht.

\section{Kokkuvõte. Ilze Tālberga, Aive Mandel: Imperfektiivsest ja perfektiivsest} aspektist eesti ja läti keeles. Artiklis uuritakse imperfektiivse ja perfektiivse aspekti vastandust võrdlevalt eesti ja läti keeles. Selleks kasutatavad näited pärinevad eesti ja läti ilukirjandusteostest ning nende vastastikustest tõlgetest. Käesolevas analüüsis on keskendutud transitiivsetele verbidele, mis nõuavad objekti. Edaspidises uurimistöös loodetakse võtta vaatluse alla ka intransitiivsed verbid. Eesti keeles on keskseks perfektiivsuse markeerimise vahendiks objektikääne. Perfektiivsust väljendab totaalobjekt (ainsuse või mitmuse nominatiiv, ainsuse genitiiv). Läti keeles väljendatakse perfektiivsust esmajoones verbiprefiksite abil, mida on kokku 11 ning mis kõik võivad (aga ei pruugi) lisaks perfektiivsusele anda verbile ka mõne muu (ruumilise, kvantitatiivse või kvalitatiivse) lisatähenduse. Kõrvutasime näitematerjali abil esmalt neid olukordi, kus eesti täisobjekti vasteks on läti keelde tõlkimisel prefiksverb, ning vaatlesime sama olukorda ka vastupidisel tõlkesuunal. Ilukirjandusnäidete põhjal tuleb neist näidetest lisaks perfektiivsuse vastavusele hästi välja ka läti prefiksi lisatähendus. Teiseks toimivad eesti keeles perfektiivsuse väljendamise vahendina ka verbipartiklid (nt $\ddot{a r a}$ ), mis võivad kas aidata totaalobjektis juba kajastuvat perfektiivsust kinnitada või on teatud juhtudel ka obligatoorsed. See mehhanism aitab kompenseerida eesti keeles ajalooliste muutuste tõttu vähem eristuvaks muutunud objektikäänete ebaselgust võrreldes nt soome keelega, kus eesti keelest sagedamini piisab perfektiivsuse väljendamiseks pelgalt objektikäändest. Tõlkekõrvutuste põhjal järeldub, et eesti verbipartiklit saab läti keeles väljendada verbiprefiksiga, milles võib avalduda lisaks perfektiivsusele ka lisatähendus (aiz- - 'kinni'). Lisatähendus võib ka puududa (iz-mazgāt - 'ära pesema'), viimasel juhul väljendatakse nii partikli kui ka prefiksiga vaid perfektiivsust. Eesti verbipartiklit võidakse aga läti keeles väljendada ka prefiksverbiga, millele lisandub samatähenduslik adverb. Kuna sellist adverbikasutust ei peeta läti keeles aspekti osaks, sest perfektiivsus väljendub juba prefiksis, siis võib neid tõlgendada ruumilist suunda rõhutavatena. Mõlemal tõlkesuunal on näha, et kui prefiksverb on juba olemas, siis sellele läti keeles lisatud adverb eestikeelset vastet ei mõjuta - eesti keeles esineb siis samasugune vaste, nagu oleks adverbita prefiksverbi puhul, kuna ka prefiksverbis on sama rumilisus juba esindatud. Mõlemad keeled kasutavad siis sel juhul paralleelselt adverbe.

Imperfektiivsust saab eesti keeles väljendada osaobjektiga (partitiiv), mis aga võib sõltuvalt kontekstist kanda ka perfektiivset tähendust. Läti keeles on imperfektiivse tõlgendusega osaobjekti vasteks prefiksita verb, mis ilmneb 
mõlemal keelesuunal ka tõlkematerjalis. Lisaks on läti keeles võimalik imperfektiivsust väljendada konstruktsiooniga prefiksita verb + adverb, milles esinev adverb on prefiksiga samatähenduslik. Nii on konstruktsioonis perfektiivsust väljendav prefiks asendatud samasisulise adverbiga, saavutades imperfektiivse tähenduse. Ka selle konstruktsiooni puhul võib näha tõlkenäidetes eesti vastena osaobjekti partitiivis, mille tõlkevastena võib omakorda eesti-läti tõlkesuunal leida osaobjekti. Läti keele imperfektiivsete (prefiksita verb) lausenäidete vastena võib mõnel harval juhul leida eesti keeles ka progressiivtarindi.

Käesolev uurimus tõi perfektiivsuse ja imperfektiivsuse väljendamisel eesti ja läti keeles välja rea omavahelisi paralleele, erinevusi ja ka sarnasusi. Artikkel on mõeldud esmase sissejuhatusena väga laia teemasse, mille käsitlemisel oleks edaspidi tarvilik nii märksa avaram vaatepunkt (nt kaasata intransitiivsed verbid ja laiendada aspekti käsitlust) kui ka põhjalikum ja mitmekülgsem uurimismaterjal.

Märksõnad: aspekt, imperfektiivsus, perfektiivsus, verbid, prefiksverbid, adverbid, läti keel, eesti keel 